\title{
AC 2011-1778: UNIT OPERATIONS LAB BAZAAR: INCORPORATION OF LABORATORY EXPERIENCES IN SIX INTEGRATED PILLAR COURSES
}

\section{Michael Jefferson Baird, University of Pittsburgh}

Dr. Baird joined the chemical engineering department at the University of Pittsburgh in the spring of 2008 as Instructor of Undergraduate Laboratory Courses. He also teaches a graduate course entitled "Petroleum and Natural Gas Processing". Before joining the University of Pittsburgh, Dr. Baird was an associate professor of chemistry at Wheeling Jesuit University for nine years following his retirement from the U.S. Department of Energy. While at DOE's National Energy Technology Laboratory (NETL) in Pittsburgh, Dr. Baird managed projects involving the conversion of coal liquids to gasoline and environmental monitoring of SO2, NOx from coal-fired power plants. From 1978 until 1988, Dr. Baird was employed at Ashland Oil (two years) and at Amoco Oil (eight years), working on hydrocracking and resid processes for producing gasoline. From 1973 until 1978, Baird was a research chemical engineer at the Pittsburgh Energy Research Center (PETC), now NETL, where he worked on Fischer-Tropsch catalysis and process development.

\section{Schohn L. Shannon, University of Pittsburgh}

Dr. Shannon joined the University of Pittsburgh in 1995 as Assistant Dean of Engineering and Chemical Engineering Lecturer following the completion of his Ph.D. at Pitt in 1995. He is also currently Executive Director of the Swanson Center for Product Innovation at Pitt and undergraduate laboratory coordinator for Chemical Engineering. Prior to joining Pitt, he worked in industry as General Manager and then Director of R\&D at Altamira Instruments, a manufacturer of catalyst characterization equipment and bench-scale reactor systems. His areas of expertise are in heterogeneous catalysis, reactor design, and steady-state isotopic transient kinetic analysis. 


\title{
Unit Operations Lab Bazaar: Incorporation of Laboratory Experiences in Six Integrated Pillar Courses
}

\begin{abstract}
The NSF-funded "Pillars of Chemical Engineering" program was implemented in 2003 at the University of Pittsburgh's Swanson School of Engineering, with the traditional undergraduate courses in chemical engineering restructured into six Pillar or core courses. ${ }^{1}$ The purpose was to develop a completely integrated chemical engineering curriculum with one of the six Pillar courses taught each semester, beginning in the fall of the sophomore year. The Pillars are designed to introduce students to engineering fundamentals in mass and energy balances, thermodynamics, kinetics, transport phenomena, process control, and design while providing an accompanying laboratory experience for each Pillar. These six Pillar courses take advantage of block scheduling with each course taught five days per week in two hour sessions - three days for lecture, one day for problem recitation, and one day for an associated laboratory course over a fifteen week semester.
\end{abstract}

The ability to provide an accompanying laboratory experience for each course, which is often not possible in a traditional curriculum, is a major advantage in the Pillar curriculum. In each laboratory course, students work in teams and each team performs two experiments per semester. While the primary objective of the accompanying laboratory experiences is to reinforce the student's understanding of the lecture material with hands-on application, the laboratory courses are structured to develop and test student's abilities to organize, work within teams, develop experimental capabilities, analyze data, and follow through on technical projects with a concentrated effort on practicing communication skills - both written and oral.

Hence, an additional major advantage of the Pillar format is it permits the implementation, starting in the sophomore year, of structured laboratory experiences involving a total of twelve different experiments throughout the undergraduate studies. This structure enables repeated reinforcement which enhances their theoretical understanding of the material and provides for longer term development of the student's teaming, technical, experimental, and communication skills.

This paper discusses the required logistics that have been developed to handle laboratory courses that accompany our Pillar courses and their advantages, as well as potential disadvantages. It presents a preliminary assessment of the effectiveness of this approach based upon a 5-point Likert scale student survey.

\section{Objective}

The objective of this study is to assess the learning experiences of sophomore and junior undergraduate chemical engineering students in two laboratory courses during the 2010 Fall Semester that were designed to introduce students to engineering fundamentals. 
Introduction

In 2003, our 1-hour, 3-credit core chemical engineering courses were restructured and integrated into six "Pillar" courses. ${ }^{1}$ The purpose was to develop a completely integrated chemical engineering curriculum with one Pillar course taught each semester, beginning at the start of the sophomore year through the senior year (see Table 1). The Pillars were designed to introduce students to engineering fundamentals in mass and energy balances, thermodynamics, kinetics, transport phenomena, process control, and design.

\section{Table 1. Pillar Laboratory Courses Integrated with Six Core Chemical Engineering Lecture Courses}

\begin{tabular}{|l|l|l|l|}
\hline \multicolumn{1}{|c|}{ Year } & Lab Course \# & Semester & Pillar Course \\
\hline Sophomore & ChE 101 & Fall & Foundations of Chemical Engineering \\
\hline & ChE 201 & Spring & Thermodynamics \\
\hline Junior & ChE 301 & Fall & Transport Phenomena \\
\hline & ChE 401 & Spring & Reactive Process Engineering \\
\hline Senior & ChE 501 & Fall & Dynamics and Modeling \\
\hline & ChE 601 & Spring & Process and Product Design and Safety \\
\hline
\end{tabular}

These six Pillar courses take advantage of block scheduling with each course taught five days per week in two hour sessions - three days for lecture, one day for problem recitation, and one day for an associated laboratory course over a fifteen week semester. A new key element of the Pillar curriculum, the associated lab course, replaced our two previous 3- and 4-credit senioryear, unit operations laboratory courses with a 1-credit lab taken each semester starting at the beginning of the sophomore year, providing an accompanying laboratory experience for each Pillar.

Lab Organization

Each student conducts two different experiments per semester and will perform twelve experiments from the sophomore through the senior year. Students work in teams to conduct each experiment and to generate two written lab reports for each experiment. Each team consists of 3-5 students with the number being dependent on enrollment and number of experiments being conducted. Each student is required to make one presentation per lab course. The reporting and presentation requirements for each experiment are similar.

In the development of the Pillar courses it was recognized that lab courses would need to be offered twice per week in order to handle an increasing enrollment while maintaining a manageable number of students per group (3-5). In this scenario, half of the students attended lab while the other half attended recitation on the same day. On a different day the order was reversed. The remaining three days were scheduled for lecture. 
In this study, 90 students taking the first lab course (ChE 101) and 78 students taking the third lab course (ChE 301) were divided into two groups that would meet on alternating days. In order to maintain teams of 3-5 students with each team conducting a different experiment on any given lab session, students were again divided and would attend lab sessions only on alternating weeks. When a student was not in lab, the student attended recitation. Table 2 is the course schedule for half of the students in ChE 301 that were again divided into two groups (Team Set I and Team Set II) that met lab sessions on alternating weeks. Each team set consisted of 5 teams of 45 students. Each team conducted a different experiment for the first half of the semester, then a second experiment for the second half of the course.

Table 2. Course Schedule for ChE 301 for the First Half of the Semester.

\begin{tabular}{|c|l|l|}
\hline Week & \multicolumn{1}{|c|}{ Laboratory/Recitation } & \multicolumn{1}{c|}{ Due } \\
\hline 1 & Introduction - All Team Sets & \\
\hline 2 & $\begin{array}{l}\text { Lab Session I-1 - Team Set I } \\
\text { Team Set II to Recitation }\end{array}$ & Progress Report I due for Team Set I \\
\hline 3 & $\begin{array}{l}\text { Lab Session I-1 - Team Set II } \\
\text { Team Set I to Recitation }\end{array}$ & Progress Report I due for Team Set II \\
\hline 4 & $\begin{array}{l}\text { Lab Session I-2 - Team Set I } \\
\text { Team Set II to Recitation }\end{array}$ & $\begin{array}{l}\text { Lab Session I-2 - Team Set II } \\
\text { Team Set I to Recitation }\end{array}$ \\
\hline 5 & Presentation Session I - Team Set I & Final Report I - Team Set I \\
\hline 7 & Presentation Session I- Team Set II & Final Report I - Team Set II \\
\hline
\end{tabular}

All students in a group received the same grade for the progress and final reports. Each student presented a 6-7 minute power point presentation on a section of the report for an individual grade. Half of the students in a group made presentations on the first assigned experiment and the remainder presented on the second experiment.

The only lab lecture given by the instructor was a 2 hour introductory lecture during the first week of the semester. At this time the syllabus, lab reports, presentations and grading were described in detail. Students were also given an overview of each of the 5 experiments.

\section{Assessment Survey}

A 5-level Likert scale was used to assess the learning experiences of students nearing completion of their lab courses during the Fall Semester of 2010. This survey was similar to a Likert scale survey that had been conducted for several years for the senior-level Dynamics and Modeling ChE 501 Process Control course. ${ }^{2}$ That ChE 501 survey was slightly different due to the nature of that course; therefore, only a portion of the ChE 501 results can potentially be applied to this survey and will be considered in future work. 
The sophomore students in $\mathrm{ChE} 101$ had attended the first of their 6 Pillar lab courses while the junior students in ChE 301 had previously completed two lab courses (ChE 101 and 201) making this their third Pillar lab course. Except for the subject of the experiments, the ChE 101, 201 and 301 courses were organized and conducted in a similar manner by the same instructor. The assessment was conducted by having the students voluntarily complete a survey that was administered on the university's course web site during the last week of the semester. To encourage student participation, 5 points was added to the 850 maximum course points for completing the survey. As a result, $84 \%$ and $86 \%$ of the students in ChE 101 and 301 responded, respectively.

The online survey included the following 5 assessment statements:

1. My ability to write a technical report has improved.

2. I am more able to assess technical quality in my work.

3. I am more able to assess proper organization for the purpose of clarity in writing.

4. My ability to design relevant experiments to achieve an objective has improved.

5. My ability to build on the results of others has improved.

For each statement, the students responded to a Likert scale with the following six choices: (a) strongly agree, (b) agree, (c) neither agree or disagree, (d) disagree, (e) strongly disagree, and (f) not applicable.

Following each of the above statements, students were subsequently asked to identify the single factor most responsible for the change. The six possible answers were:

1. Feedback from the Instructor.

2. Having to write multiple reports.

3. Having to run multiple experiments.

4. Listening to presentations from other teams.

5. Having to work in a team.

6. Not applicable.

The last question on the survey was an open written-response asking the students to comment on how the repetitive structure of the $\mathrm{ChE}$ lab course has impacted their education and academic development.

Results of the Survey

Of 90 students in ChE 101, 76 responded and 67 of the 78 students in ChE 301 responded. The percent of students' responses from both courses are compared in Table 3. The number of respondents per question for $\mathrm{ChE} 101$ and $\mathrm{ChE} 301$ are tabulated in Tables 4 and 5, respectively and are presented at the end of the paper.

\section{Discussion of Results}

It is important to note that this survey reflects the student attitudes towards the lab courses and does not provide a direct measurement of the actual student performance and command of the course material due to the lab -- the latter can only be qualitatively assessed at this time. Direct 


\section{Table 3. Assessment of Learning Experiences for ChE 101 and ChE 301 Expressed as a Percent of Total Responses During the 2010 Fall Semester}

1. My ability to write a technical report has improved

\begin{tabular}{|c|c|c|c|c|c|}
\hline 1. Strongly Agree & 2. Agree & $\begin{array}{l}\text { 3. Neither Agree } \\
\text { or Disagree }\end{array}$ & 4. Disagree & $\begin{array}{l}\text { 5. Strongly } \\
\text { Disagree }\end{array}$ & 6. Not Applicable \\
\hline $23.7 \%^{1}$ & $71.6 \%$ & $2.6 \% \quad 6.0 \%$ & 0 & $0 \quad 0$ & 0 \\
\hline \multicolumn{6}{|c|}{ 2. The single factor most responsible for this change is: } \\
\hline $\begin{array}{l}\text { 1. Feedback from } \\
\text { Instructor. }\end{array}$ & $\begin{array}{l}\text { 2. Having to write } \\
\text { multiple reports. }\end{array}$ & $\begin{array}{l}\text { 3. Having to run } \\
\text { multiple } \\
\text { experiments. }\end{array}$ & $\begin{array}{l}\text { 4. Listening to } \\
\text { presentations } \\
\text { from other teams. }\end{array}$ & $\begin{array}{l}\text { 5. Having to work } \\
\text { in a team. }\end{array}$ & 6. Not Applicable \\
\hline $32.8 \%$ & $56.7 \%$ & $3.9 \% \quad 1.5 \%$ & $1.3 \% \quad 0$ & $10.5 \%$ & $3.9 \%$ \\
\hline
\end{tabular}

3. I am more able to assess technical quality in my work.

\begin{tabular}{|c|c|c|c|c|c|}
\hline 1. Strongly Agree & 2. Agree & $\begin{array}{l}\text { 3. Neither Agree } \\
\text { or Disagree }\end{array}$ & 4. Disagree & $\begin{array}{l}\text { 5. Strongly } \\
\text { Disagree }\end{array}$ & 6. Not Applicable \\
\hline $17.9 \%$ & $72.4 \%$ & $11,8 \% \quad 11.9 \%$ & $1.3 \%$ & 0 & 0 \\
\hline
\end{tabular}

4. The single factor most responsible for this change is:

\begin{tabular}{|c|c|c|c|c|c|}
\hline $\begin{array}{l}\text { 1. Feedback from } \\
\text { Instructor. }\end{array}$ & $\begin{array}{l}\text { 2. Having to write } \\
\text { multiple reports. }\end{array}$ & $\begin{array}{l}\text { 3. Having to run } \\
\text { multiple } \\
\text { experiments. }\end{array}$ & $\begin{array}{l}\text { 4. Listening to } \\
\text { presentations } \\
\text { from other teams. }\end{array}$ & $\begin{array}{l}\text { 5. Having to work } \\
\text { in a team. }\end{array}$ & 6. Not Applicable \\
\hline $44.8 \%$ & $22.4 \%$ & $14.5 \%$ & $3.0 \%$ & $5.3 \%$ & $3.9 \%$ \\
\hline
\end{tabular}

5. I am more able to assess proper organization for the purpose of clarity in writing.

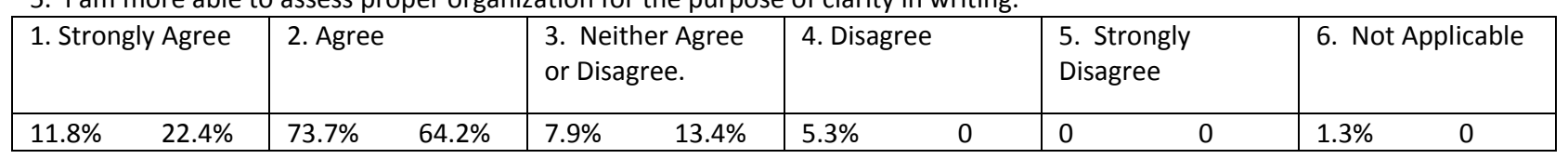

6. The single factor most responsible for this change is:

\begin{tabular}{|c|c|c|c|c|c|c|}
\hline $\begin{array}{l}\text { 1. Feedback from } \\
\text { Instructor. }\end{array}$ & $\begin{array}{l}\text { 2. Having to write } \\
\text { multiple reports. }\end{array}$ & $\begin{array}{l}\text { 3. Having to run } \\
\text { multiple } \\
\text { experiments. }\end{array}$ & $\begin{array}{l}\text { 4. Listening to } \\
\text { presentations } \\
\text { from other teams. }\end{array}$ & $\begin{array}{l}\text { 5. Ha } \\
\text { in a t }\end{array}$ & to work & 6. Not Applicable \\
\hline $35.8 \%$ & $41.8 \%$ & $3.0 \%$ & $3.9 \% \quad 0$ & $15.8 \%$ & $6.0 \%$ & $10.5 \%$ \\
\hline
\end{tabular}

7. My ability to design relevant experiments to achieve an objective has improved.

\begin{tabular}{|c|c|c|c|c|c|c|c|c|c|c|c|}
\hline \multicolumn{2}{|c|}{ 1. Strongly Agree } & \multicolumn{2}{|c|}{ 2. Agree } & \multirow{2}{*}{\multicolumn{2}{|c|}{$\begin{array}{l}\text { 3. Neither Agree } \\
\text { or Disagree }\end{array}$}} & \multicolumn{2}{|c|}{ 4. Disagree } & \multicolumn{2}{|c|}{$\begin{array}{l}\text { 5. Strongly } \\
\text { Disagree }\end{array}$} & \multicolumn{2}{|c|}{ 6. Not Applicable } \\
\hline $15.8 \%$ & $4.5 \%$ & $61.2 \%$ & $44.8 \%$ & $23.7 \%$ & & $3.9 \%$ & $13.4 \%$ & 0 & $1.5 \%$ & $2.6 \%$ & $6.0 \%$ \\
\hline
\end{tabular}

8. The single factor most responsible for this change is:

\begin{tabular}{|c|c|c|c|c|c|}
\hline $\begin{array}{l}\text { 1. Feedback from } \\
\text { Instructor. }\end{array}$ & $\begin{array}{l}\text { 2. Having to write } \\
\text { multiple reports. }\end{array}$ & $\begin{array}{l}\text { 3. Having to run } \\
\text { multiple } \\
\text { experiments. }\end{array}$ & $\begin{array}{l}\text { 4. Listening to } \\
\text { presentations } \\
\text { from other teams. }\end{array}$ & $\begin{array}{l}\text { 5. Having to work } \\
\text { in a team. }\end{array}$ & 6. Not Applicable \\
\hline $10.5 \%$ & $1.5 \%$ & $56.6 \% \quad 47.8 \%$ & $2.6 \% \quad 4.5 \%$ & $2.6 \%$ & $23.7 \%$ \\
\hline
\end{tabular}

9. My ability to build on the results of others has improved.

\begin{tabular}{|c|c|c|c|c|c|}
\hline 1. Strongly Agree & 2. Agree & $\begin{array}{l}\text { 3. Neither Agree } \\
\text { or Disagree. }\end{array}$ & 4. Disagree & $\begin{array}{l}\text { 5. Strongly } \\
\text { Disagree }\end{array}$ & 6. Not Applicable \\
\hline $13.2 \% \quad 17.9 \%$ & $60.5 \% \quad 70.1 \%$ & $19.7 \% \quad 7.5 \%$ & $3.0 \%$ & $0 \quad 0$ & $1.3 \%$ \\
\hline \multicolumn{6}{|c|}{ 10. The single factor most responsible for this change is: } \\
\hline $\begin{array}{l}\text { 1. Feedback from } \\
\text { Instructor. }\end{array}$ & $\begin{array}{l}\text { 2. Having to write } \\
\text { multiple reports. }\end{array}$ & $\begin{array}{l}\text { 3. Having to run } \\
\text { multiple } \\
\text { experiments. }\end{array}$ & $\begin{array}{l}\text { 4. Listening to } \\
\text { presentations } \\
\text { from other teams. }\end{array}$ & $\begin{array}{l}\text { 5. Having to work } \\
\text { in a team. }\end{array}$ & 6. Not Applicable \\
\hline $2.6 \%$ & $10.4 \%$ & $3.9 \% \quad 10.4 \%$ & $18.4 \% \quad 20.9 \%$ & $50.7 \%$ & $21.1 \%$ \\
\hline
\end{tabular}

${ }^{1}$ Percent of responses from 76 students in ChE 101

${ }^{2}$ Percent of responses from 67 students in ChE 301 
assessment would be possible if additional testing were given as part of the lab course. Unfortunately, the structure of the Pillar courses does not provide the additional time to allow this separate testing outside of the lecture. However, a somewhat mitigating advantage to date has been that the same instructors conduct the laboratories over the 6 Pillar courses, and each lab has a similar course structure. It is our qualitative observation that the ability to conduct experiments, the quality of technical report writing and oral presentations, as well as the ability to think critically, shows definite improvement from the sophomore through senior years. Within this context, we addressed each assessment statement of the survey.

\section{Ability to Write a Technical Report}

Pre-survey expectations of the survey results were that students would most likely believe that their abilities to write technical reports would improve as more lab courses were completed. The similar structure of the lab courses with respect to report writing was meant to reinforce and develop this ability through repetition and Instructor feedback on reports. However, as seen in the responses for Likert Question 1 in Table 3, there was little change between the ChE 101 sophomore and ChE 301 junior classes. For example, 23.7\% and 22.4\% of ChE 101 and 301 students strongly agree, respectively, and $73.7 \%$ vs. $71.6 \%$ agree that their ability to write a technical report improved. It appeared that the students immediately believe that their technical report writing improved which was encouraging. It was seen from follow-up Question 2 in Table 3 , however, that there was a shift in the students' belief as to reason the for this improvement, with less emphasis on Instructor feedback and more on simple iterative writing of multiple reports indicated by the $42.1 \%$ increase to $56.7 \%$ between sophomores and juniors.

\section{Ability to Assess Technical Quality}

Similar to the results for the ability to write a technical report, the ability to assess the quality of a technical report as seen in Likert Question 3 in Table 3 also indicated little difference between the perception between sophomores and juniors. For example, $72.4 \%$ and $70.1 \%$, respectively, agreed that they were more able to assess the technical quality of their work. However, compared to the previous question on the improvement of their technical report writing, students tended to be more neutral on this question, with $11.8 \%$ and $11.9 \%$, respectively, neither agreeing nor disagreeing. Follow-up Question 4 in Table 3 indicates that students felt the reason for this improvement was feedback from the instructor followed by multiple report writing. This was most likely due to the students' perception that they are improving their technical capabilities through repeated lab experiences on multiple experiments.

\section{Ability to Assess Proper Organization}

When assessing if students believed that they improved their organization skills for the purpose of writing, the results for Likert Question 5 in Table 3 indicate that more junior students, 22.4\% in ChE 301, strongly agreed than sophomore students, $11.8 \%$ in ChE 101 . However, when combining the $\%$ responses of strongly agree and agree, there is little difference between sophomores and juniors, 85.5\% vs. 86.6\%, respectively. From follow-up Question 6 in Table 3, the single factor for improvement in organization was mixed. More junior ChE 301 students $(41.8 \%$ vs. $30.3 \%)$ felt writing multiple reports was responsible while more sophomore ChE 101 students $(15.0 \%$ vs. $6.0 \%)$ believed working in a team contributed to the improvement. 
Approximately the same percentage of students from both ChE 101 and ChE 301 (39.5\% vs. $35.8 \%$ ) attributed feedback from the instructor as the reason for their improvement in organization.

\section{Ability to Design Relevant Experiments}

Responses to the ability of the student to design relevant experiments, Question 7 in Table 3, appeared at first to be puzzling. More junior ChE 301 students had a neutral response or disagreed (29.8\% and $13.4 \%$, respectively) than sophomore ChE 101 students, $(23.7 \%$ and 3.9\%, respectively) while follow-up Question 8 in Table 3 indicated that the students believed that running multiple experiments was the primary reason for this improvement, which is reasonable. Each sophomore and junior experiment is well structured with fairly well defined experimental methodology. One possible reason that more juniors may have felt that they were not improving their experimental design capability was that, while they were developing their experimental skills by running multiple experiments, they were confined by the structured labs. It should be noted that the senior level lab courses, ChE 501 and ChE 601, are less structured with more open-ended experiments. It would be valuable to compare the response of senior-level students to that of juniors in future surveys to begin to discern if this is the reason for this unexpected result.

\section{Ability to Build Upon Results of Others}

The perception of the students' ability to build upon the work of others, Question 9 in Table 3 showed a definite increase between the sophomore and junior years. More junior students, $70.1 \%$ in ChE 301, agreed than sophomore students, $60.5 \%$ in ChE 101 while the combined \% responses of strongly agree and agree indicate a difference between juniors and sophomores of $88.0 \%$ and $73.7 \%$, respectively. It should also be noted that the neutral response also decreased from $19.7 \%$ for sophomore $\mathrm{ChE} 101$ students to $7.5 \%$ for junior ChE 301 students. Follow-up Question 10 in Table 3 indicated that the students believed that having to work within a team, $44.7 \%$ and $50.7 \%$ respectively, was the primary reason for this improvement which is reasonable. These results most likely indicate that students do take additional time in developing their ability to work in a team environment. However, it also indicated that they feel another relatively substantial reason ( $18.4 \%$ and $20.9 \%$ respectively) is listening to presentations from other teams indicating that both internal (within their own team) and external (other teams) interactions affect their perception.

\section{Written Response Summary}

An open, written response question, "Please comment on how the repetitive structure of the $\mathrm{ChE}$ lab course has impacted your education and academic development." was posed to the students. The responses from each course were subjectively rated as Positive, Negative, or Neutral by the instructor. The results for sophomore level ChE 101 were $87.5 \%$ Positive, $6.9 \%$ Negative and $5.6 \%$ Neutral (4 of the 76 students did not answer) and for junior level ChE 301 they were $85.7 \%, 11.1 \%$, and $3.2 \%$, respectively ( 4 of 67 students did not answer). The principal subject of the Negative responses was that the student's felt the repetitiveness was "boring" and increased for the juniors, apparently since they had taken more lab courses. 


\section{Conclusions}

It appears that the students believe that their technical report writing immediately improves during their first lab course as sophomores, but their perception as to the reason for this improvement changes from feedback from the instructor during their sophomore lab course to a reason of more repetitive writing for juniors. The students' perception of their ability to assess the technical quality of their work also follows the results of their ability to write technical reports, including both feedback from the instructor and having to write multiple reports, but also includes having to run multiple experiments.

When the students assessed their ability to organize for the purpose of writing, there was little difference between sophomore and junior classes with the reasons of writing multiple reports and feedback form the instructor being perceived to be equally responsible for improvement. The perception of the students' ability to build upon the work of others showed a definite increase between the sophomore and junior years attributable to an increase in the students' belief that having to work within a team was the primary reason for this improvement -- students most likely need additional time to develop their ability to work in a team environment and do so over several courses.

Perhaps the greatest dichotomy in the results of this survey was the student responses to their ability to design relative experiments. More juniors had a neutral response or disagreed than sophomores - the opposite of what might be expected as students should develop greater experimental acumen as they perform more experiments. One reason may be that juniors may feel that they are confined by the structured labs, thereby limiting their perceived improvement in experimental design capability.

Overall, all student answers tended towards agreement and strong agreement to the posed Likert scale questions with little disagreement. These favorable results, along with a substantial number of positive open-answer responses, indicate that the majority of students believe that the Pillar lab course structure has value in their chemical engineering education.

\section{Future Work}

This Likert scale survey is an initial study of a planned longer study that will follow students through the 6 integrated Pillar labs. We will be surveying $2^{\text {nd }}$ semester seniors which will complete this academic year's survey for comparison with the current sophomore and junior survey to possibly further substantiate some of the reasoning that we have applied to date.

One trend that we will be looking for from this senior survey is whether the student's perception of their ability to design relevant experiments finally improves or not. As previously stated, a possible reason for a decline in this perception between the junior and sophomore years may have been the continued structured experiments. While the written and oral reporting structure are maintained, the experimental structure is somewhat relaxed in the senior year courses - the experiments are more open ended - and a perceived increase in the ability to design experiments might be expected as a result. In any event, a more open-ended, experimental-design capstone lab course at the end of their senior year is being considered that would present the students with 
an engineering problem related to the experiment and require the students to develop their experiments to investigate solutions. A follow up survey will also help to ascertain the success of this course implementation.

We will subsequently survey first semester sophomores and juniors, and second semester seniors during the next academic year. There is a concern that, if the same survey is given each semester to the same group of students over 6 semesters, the familiarity of the survey will alter the results - the students may tend to simply repeat their survey answers without great forethought to the questions. By conducting the surveys during the first half of each academic year for the sophomores and juniors, students will not be taking back-to-back surveys over three years. This should enable us to evaluate less-biased survey results.

\section{References}

1. McCarthy, J.J. and Parker, R. S., "The Pillars of Chemical Engineering: A Block Scheduled Curriculum", Chemical Engineering Education, 38 (4), 292-301, 2004.

2. Parker, R.S. and Shannon, S.L., "Pillars of ChE: Systems Eng. I. An Integrated Course and Laboratory," ASEE 2008 Conference, Pittsburgh, PA. 


\section{Table 4. Survey of Learning Experiences of ChE 101 Students During the Fall of 2010 (76 Responses from a Class of 90 Students)}

1. My ability to write a technical report has improved.

\begin{tabular}{|c|c|c|c|c|c|}
\hline 1. Strongly Agree & 2. Agree & $\begin{array}{l}\text { 3. Neither Agree } \\
\text { or Disagree }\end{array}$ & 4. Disagree & $\begin{array}{l}\text { 5. Strongly } \\
\text { Disagree }\end{array}$ & 6. Not Applicable \\
\hline 18 & 56 & 2 & 0 & 0 & 0 \\
\hline \multicolumn{6}{|c|}{ 2. The single factor most responsible for this change is: } \\
\hline $\begin{array}{l}\text { 1. Feedback from } \\
\text { Instructor. }\end{array}$ & $\begin{array}{l}\text { 2. Having to write } \\
\text { multiple reports. }\end{array}$ & $\begin{array}{l}\text { 3. Having to run } \\
\text { multiple } \\
\text { experiments. }\end{array}$ & $\begin{array}{l}\text { 4. Listening to } \\
\text { presentations } \\
\text { from other teams. }\end{array}$ & $\begin{array}{l}\text { 5. Having to work } \\
\text { in a team. }\end{array}$ & 6. Not Applicable \\
\hline 29 & 32 & 3 & 1 & 8 & 3 \\
\hline
\end{tabular}

3. I am more able to assess technical quality in my work.

\begin{tabular}{|l|l|l|l|l|l|}
\hline 1. Strongly Agree & 2. Agree & $\begin{array}{l}\text { 3. Neither Agree } \\
\text { or Disa. }\end{array}$ & 4. Disagree & $\begin{array}{l}\text { 5. Strongly } \\
\text { Disagree }\end{array}$ & 6. Not Applicable \\
\hline 11 & 55 & 9 & 1 & 0 & 0 \\
\hline \begin{tabular}{|l|l|l|l|l|} 
4. The single factor most responsible for this change is: \\
Instructor.
\end{tabular} & $\begin{array}{l}\text { 2. Having to write } \\
\text { multiple reports. }\end{array}$ & $\begin{array}{l}\text { 3. Having to run } \\
\text { multiple } \\
\text { experiments. }\end{array}$ & $\begin{array}{l}\text { 4. Listening to } \\
\text { presentations } \\
\text { from other teams. }\end{array}$ & $\begin{array}{l}\text { 5. Having to work } \\
\text { in a team. }\end{array}$ & 6. Not Applicable \\
\hline 33 & 25 & 11 & 0 & 4 & 3 \\
\hline
\end{tabular}

5. I am more able to assess proper organization for the purpose of clarity in writing.

\begin{tabular}{|c|c|c|c|c|c|}
\hline 1. Strongly Agree & 2. Agree & $\begin{array}{l}\text { 3. Neither Agree } \\
\text { or Disa. }\end{array}$ & 4. Disagree & $\begin{array}{l}\text { 5. Strongly } \\
\text { Disagree }\end{array}$ & 6. Not Applicable \\
\hline 9 & 56 & 6 & 4 & 0 & 1 \\
\hline \multicolumn{6}{|c|}{ 6. The single factor most responsible for this change is: } \\
\hline $\begin{array}{l}\text { 1. Feedback from } \\
\text { Instructor. }\end{array}$ & $\begin{array}{l}\text { 2. Having to write } \\
\text { multiple reports. }\end{array}$ & $\begin{array}{l}\text { 3. Having to run } \\
\text { multiple } \\
\text { experiments. }\end{array}$ & $\begin{array}{l}\text { 4. Listening to } \\
\text { presentations } \\
\text { from other teams. }\end{array}$ & $\begin{array}{l}\text { 5. Having to work } \\
\text { in a team. }\end{array}$ & 6. Not Applicable \\
\hline 30 & 23 & 0 & 3 & 12 & 8 \\
\hline
\end{tabular}

7. My ability to design relevant experiments to achieve an objective has improved.

\begin{tabular}{|c|c|c|c|c|c|}
\hline 1. Strongly Agree & 2. Agree & $\begin{array}{l}\text { 3. Neither Agree } \\
\text { or Disa. }\end{array}$ & 4. Disagree & $\begin{array}{l}\text { 5. Strongly } \\
\text { Disagree }\end{array}$ & 6. Not Applicable \\
\hline 12 & 41 & 18 & 3 & 0 & 2 \\
\hline \multicolumn{6}{|c|}{ 8. The single factor most responsible for this change is: } \\
\hline $\begin{array}{l}\text { 1. Feedback from } \\
\text { Instructor. }\end{array}$ & $\begin{array}{l}\text { 2. Having to write } \\
\text { multiple reports. }\end{array}$ & $\begin{array}{l}\text { 3. Having to run } \\
\text { multiple } \\
\text { experiments. }\end{array}$ & $\begin{array}{l}\text { 4. Listening to } \\
\text { presentations } \\
\text { from other teams. }\end{array}$ & $\begin{array}{l}\text { 5. Having to work } \\
\text { in a team. }\end{array}$ & 6. Not Applicable \\
\hline 8 & 3 & 43 & 2 & 2 & 18 \\
\hline
\end{tabular}

9. My ability to build on the results of others has improved.

\begin{tabular}{|c|c|c|c|c|c|}
\hline 1. Strongly Agree & 2. Agree & $\begin{array}{l}\text { 3. Neither Agree } \\
\text { or Disa. }\end{array}$ & 4. Disagree & $\begin{array}{l}\text { 5. Strongly } \\
\text { Disagree }\end{array}$ & 6. Not Applicable \\
\hline 10 & 46 & 15 & 4 & 0 & 1 \\
\hline \multicolumn{6}{|c|}{ 10. The single factor most responsible for this change is: } \\
\hline $\begin{array}{l}\text { 1. Feedback from } \\
\text { Instructor. }\end{array}$ & $\begin{array}{l}\text { 2. Having to write } \\
\text { multiple reports. }\end{array}$ & $\begin{array}{l}\text { 3. Having to run } \\
\text { multiple } \\
\text { experiments. }\end{array}$ & $\begin{array}{l}\text { 4. Listening to } \\
\text { presentations } \\
\text { from other teams. }\end{array}$ & $\begin{array}{l}\text { 5. Having to work } \\
\text { in a team. }\end{array}$ & 6. Not Applicable \\
\hline 2 & 7 & 3 & 14 & 34 & 16 \\
\hline
\end{tabular}




\section{Table 5. Survey of Learning Experiences of ChE 301 Students During the Fall of 2010 (67 Responses from a Class of 78 Students)}

1. My ability to write a technical report has improved.

\begin{tabular}{|l|l|l|l|l|l|}
\hline 1. Strongly Agree & 2. Agree & $\begin{array}{l}\text { 3. Neither Agree } \\
\text { or Disa. }\end{array}$ & 4. Disagree & $\begin{array}{l}\text { 5. Strongly } \\
\text { Disagree }\end{array}$ & 6. Not Applicable \\
\hline 15 & 48 & 4 & 0 & 0 \\
\hline 2. The single factor most responsible for this change is: \\
\begin{tabular}{|l|l|l|l|l|l|} 
1. Feedback from \\
Instructor.
\end{tabular} & $\begin{array}{l}\text { 2. Having to write } \\
\text { multiple reports. }\end{array}$ & $\begin{array}{l}\text { 3. Having to run } \\
\text { multiple } \\
\text { experiments. }\end{array}$ & $\begin{array}{l}\text { 4. Listening to } \\
\text { presentations } \\
\text { from other teams. }\end{array}$ & $\begin{array}{l}\text { 5. Having to work } \\
\text { in a team. }\end{array}$ & 6. Not Applicable \\
\hline 22 & 1 & 0 & 4 & 2 \\
\hline
\end{tabular}

3. I am more able to assess technical quality in my work.

\begin{tabular}{|l|l|l|l|l|l|}
\hline 1. Strongly Agree & 2. Agree & $\begin{array}{l}\text { 3. Neither Agree } \\
\text { or Disa. }\end{array}$ & 4. Disagree & $\begin{array}{l}\text { 5. Strongly } \\
\text { Disagree }\end{array}$ & 6. Not Applicable \\
\hline 12 & 47 & 8 & 0 & 0 & 0 \\
\hline \begin{tabular}{l|l|l|l|l|} 
4. The single factor most responsible for this change is: \\
Instructor.
\end{tabular} & $\begin{array}{l}\text { 2. Having to write } \\
\text { multiple reports. }\end{array}$ & $\begin{array}{l}\text { 3. Having to run } \\
\text { multiple } \\
\text { experiments. }\end{array}$ & $\begin{array}{l}\text { 4. Listening to } \\
\text { presentations } \\
\text { from other teams. }\end{array}$ & $\begin{array}{l}\text { 5. Having to work } \\
\text { in a team. }\end{array}$ & 6. Not Applicable \\
\hline 30 & 15 & 2 & 2 & 6 \\
\hline
\end{tabular}

5. I am more able to assess proper organization for the purpose of clarity in writing.

\begin{tabular}{|l|l|l|l|l|l|}
\hline 1. Strongly Agree & 2. Agree & $\begin{array}{l}\text { 3. Neither Agree } \\
\text { or Disa. }\end{array}$ & 4. Disagree & $\begin{array}{l}\text { 5. Strongly } \\
\text { Disagree }\end{array}$ & 6. Not Applicable \\
\hline 15 & 43 & 9 & 0 & 0 & 0 \\
\hline \begin{tabular}{l|l|l|l|l|l|} 
6. The single factor most responsible for this change is: \\
Instructor.
\end{tabular} & $\begin{array}{l}\text { 2. Having to write } \\
\text { multiple reports. }\end{array}$ & $\begin{array}{l}\text { 3. Having to run } \\
\text { multiple } \\
\text { experiments. }\end{array}$ & $\begin{array}{l}\text { 4. Listening to } \\
\text { presentations } \\
\text { from other teams. }\end{array}$ & $\begin{array}{l}\text { 5. Having to work } \\
\text { in a team. }\end{array}$ & 6. Not Applicable \\
\hline 24 & 28 & 0 & 4 & 9 \\
\hline
\end{tabular}

7. My ability to design relevant experiments to achieve an objective has improved.

\begin{tabular}{|l|l|l|l|l|l|}
\hline 1. Strongly Agree & 2. Agree & $\begin{array}{l}\text { 3. Neither Agree } \\
\text { or Disa. }\end{array}$ & 4. Disagree & $\begin{array}{l}\text { 5. Strongly } \\
\text { Disagree }\end{array}$ & 6. Not Applicable \\
\hline 3 & 30 & 20 & 9 & 1 & 4 \\
\hline \begin{tabular}{|l|l|l|l|l|l|} 
8. The single factor most responsible for this change is: \\
Instructor.
\end{tabular} & $\begin{array}{l}\text { 2. Having to write } \\
\text { multiple reports. }\end{array}$ & $\begin{array}{l}\text { 3. Having to run } \\
\text { multiple } \\
\text { experiments. }\end{array}$ & $\begin{array}{l}\text { 4. Listening to } \\
\text { presentations } \\
\text { from other teams. }\end{array}$ & $\begin{array}{l}\text { 5. Having to work } \\
\text { in a team. }\end{array}$ & 6 . Not Applicable \\
\hline 0 & 1 & 32 & 3 & 4 & 27 \\
\hline
\end{tabular}

9. My ability to build on the results of others has improved.

\begin{tabular}{|c|c|c|c|c|c|}
\hline 1. Strongly Agree & 2. Agree & $\begin{array}{l}\text { 3. Neither Agree } \\
\text { or Disa. }\end{array}$ & 4. Disagree & $\begin{array}{l}\text { 5. Strongly } \\
\text { Disagree }\end{array}$ & 6. Not Applicable \\
\hline 12 & 47 & 5 & 2 & 0 & 1 \\
\hline \multicolumn{6}{|c|}{ 10. The single factor most responsible for this change is: } \\
\hline $\begin{array}{l}\text { 1. Feedback from } \\
\text { Instructor. }\end{array}$ & $\begin{array}{l}\text { 2. Having to write } \\
\text { multiple reports. }\end{array}$ & $\begin{array}{l}\text { 3. Having to run } \\
\text { multiple } \\
\text { experiments. }\end{array}$ & $\begin{array}{l}\text { 4. Listening to } \\
\text { presentations } \\
\text { from other teams. }\end{array}$ & $\begin{array}{l}\text { 5. Having to work } \\
\text { in a team. }\end{array}$ & 6. Not Applicable \\
\hline 0 & 7 & 7 & 14 & 34 & 5 \\
\hline
\end{tabular}




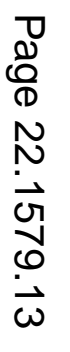

